\title{
The Incidence of Public Spending on Healthcare: Comparative Evidence from Asia
}

\author{
Owen O’Donnell, Eddy van Doorslaer, Ravi P. Rannan-Eliya, \\ Aparnaa Somanathan, Shiva Raj Adhikari, Deni Harbianto, \\ Charu C. Garg, Piya Hanvoravongchai, Mohammed N. Huq, \\ Anup Karan, Gabriel M. Leung, Chiu Wan Ng, Badri Raj Pande, \\ Keith Tin, Kanjana Tisayaticom, Laksono Trisnantoro, \\ Yuhui Zhang, and Yuxin Zhao
}

\begin{abstract}
The article compares the incidence of public healthcare across 11 Asian countries and provinces, testing the dominance of healthcare concentration curves against an equal distribution and Lorenz curves and across countries. The analysis reveals that the distribution of public healthcare is prorich in most developing countries. That distribution is avoidable, but a propoor incidence is easier to realize at higher national incomes. The experiences of Malaysia, Sri Lanka, and Thailand suggest that increasing the incidence of propoor healthcare requires limiting the use of user fees, or protecting the poor effectively from them, and building a wide network of health facilities. Economic growth may not only relax the government budget constraint on propoor policies but also increase propoor incidence indirectly by raising richer individuals' demand for private sector alternatives. JEL Codes: H22, H42, H51.
\end{abstract}

Owen O'Donnell (corresponding author) is an assistant professor of quantitative methods at the University of Macedonia, Greece; his email address is ood@uom.gr. Eddy van Doorslaer is a professor of health economics at Erasmus University, the Netherlands; his email address is vandoorslaer@few.eur. nl. Ravi P. Rannan-Eliya is director of the Institute for Health Policy in Sri Lanka; his email address is ravi@ihp.lk. Aparnaa Somanathan is a fellow at the Institute for Health Policy, Sri Lanka; her email address is aparanaa@ihp.lk. Badri Raj Pande is the director of the Nepal Health Economics Association; his email address is neil@info.com.np. Shiva Raj Adhikari is a researcher at the Nepal Health Economics Association; his email address is sssadhikari@yahoo.com. Laksono Trisnantoro is a professor of health policy at Gadjah Mada University, Indonesia; his email address is trisnantoro@ yahoo.com. Deni Harbianto is a researcher at Gadjah Mada University, Indonesia; his email address is d_harbianto@yahoo.com. Charu C. Garg is a health economist at the World Health Organization; her email address is gargc@who.int. Piya Hanvoravongchai is a researcher at the International Health Policy Programme, Thailand; his email address is piyaorn@ihpp.thaigov.net. Kanjana Tisayaticom is a researcher at the International Health Policy Programme, Thailand; her email address is kanjana@ihpp. thaigov.net. Mohammed N. Huq is a lecturer at Jahangirnagar University, Bangladesh; his email address is m_nazmul@proshikanet.com. Anup Karan is a Takemi Fellow at the Harvard School of Public Health; his email address is akaran@hsph.harvard.edu. Gabriel M. Leung is a professor of

THE WORLD BANK ECONOMIC REVIEW, VOL. 21, NO. 1, pp. 93-123

doi:10.1093/wber/lhl009

Advance Access Publication 24 January 2007

(C) The Author 2007. Published by Oxford University Press on behalf of the International Bank for Reconstruction and Development / THE WORLD BANK. All rights reserved. For permissions, please e-mail: journals.permissions@oxfordjournals.org 
Propoor public spending on healthcare and other services is a stated objective of national governments and international agencies. It is central to the mission of the World Bank and is a key component of the Heavily Indebted Poor Countries Initiative and the International Monetary Fund's Poverty Reduction and Growth Facility. Motivations include redressing inequity in the distribution of healthcare, reducing health inequality, and raising the human capital of the poor and thereby the growth potential of the economy. In low-income countries, where administrative constraints on redistribution through cash transfers are particularly binding, a subsidiary justification for public spending on healthcare may be the alleviation of poverty and the reduction of inequality (Besley and Coate 1991). The validity of these arguments for public spending on healthcare rests on the empirical question of whether the spending is in fact targeted to the poor.

Benefit incidence analysis identifies the recipients of public spending in relation to their position in the income distribution. Benefit incidence studies, many conducted by the World Bank, generally find that public spending on healthcare in developing countries is not concentrated on the poor (van de Walle 1995; Castro-Leal and others 2000; Mahal and others 2000; Sahn and Younger 2000; Filmer 2003). Most of these studies have been conducted on an ad hoc basis, with relatively little attention to consistency in methods. Limitations in the comparability of the evidence make it difficult to draw lessons about the economic, political, and health system characteristics that explain greater and lesser success in targeting health spending to the poor.

This article presents comparable evidence on the incidence of public health spending using consistent methods across eight Asian countries (Bangladesh, India, Indonesia, Malaysia, Nepal, Sri Lanka, Thailand, and Vietnam) and three Chinese provinces or regions (Gansu, Heilongjiang, and Hong Kong Special Administrative Region). Dominance tests are used to determine whether the distribution of public healthcare deviates significantly from perfect equality. Many indicators show that poorer individuals are generally less healthy (Gwatkin and others 2003) and, one may presume, in greater need of healthcare. From an egalitarian perspective an equitable distribution of healthcare demands that resources be concentrated on the poor. Evidence that the

translational public health at the University of Hong Kong; his email address is gmleung@hku.hk. Keith Tin is a researcher at the University of Hong Kong; his email address is tinyiukei@hkusua.hku.hk. Chiu Wan Ng is a lecturer at the University of Malaya, Malaysia; her email address is chiuwan.ng@ummc. edu.my. Yuxin Zhao is a professor of health economics at the National Health Economics Institute, China; her email address is yuxin.zhao@cnhei.edu.cn. Yuhui Zhang is a researcher at the National Health Economics Institute, China; his email address is zyh@nhei.cn. The authors thank three anonymous referees and the editor for valuable comments. The European Commission International Research Cooperation with Developing Countries (INCO-DEV) program (ICA4-CT-2001-10015) funded the Equity in Asia-Pacific Health Systems (Equitap) project from which this article derives. The Health, Welfare, and Food Bureau of the government of the Hong Kong Special Administrative Region funded the analysis for Hong Kong. A supplemental appendix to this article is available at http://wber. oxfordjournals.org/. 
poor do not receive their population share of health spending would be sufficient to reject equity in the allocation of public healthcare. While the main justification for public provision of healthcare is likely to be its impact on the level and distribution of population health, redistribution of living standards may be a further motivation in largely informal economies that are constrained in the execution of tax and cash transfer policies. ${ }^{1}$ To assess the redistributive impact of public health spending, its distribution is compared with the Lorenz curve of household income.

One limitation of many previous benefit incidence studies is the crudeness of the unit cost data used to value services (van de Walle 1998; Sahn and Younger 2000). This study derives costs from detailed health accounts, available for most of the countries and provinces, which document public expenditures across health services, facilities, and regions. This allows examination of whether conclusions about the incidence of public healthcare are sensitive to analysis of use or expenditure data.

Data and methods are described in the next section and results are presented and discussed in section II. The findings are summarized in section III.

\section{Data AND Methods}

The objective is to estimate and assess the distribution of public healthcare in relation to economic status. For each country data are from recent health or socioeconomic surveys that provide information on both use of public healthcare and a suitable measure of living standards (see table S-1 in the supplemental appendix, available at http://wber.oxfordjournals.org/). All are nationally representative except for the surveys of Chinese provinces. The preferred proxy for living standards is household (per adult equivalent) consumption, which includes the value of goods produced by the household for its own consumption and a use-value of housing and durable goods. ${ }^{2}$ Household expenditure, rather than consumption, is used for Hong Kong SAR, where household production is much less significant. For Malaysia the only available measure of living standards included in the health survey is household income, which is likely to understate the living standards of rural households. It is, however, the measure that has been used in previous incidence studies of Malaysia (Meerman 1979; Hammer, Nabi, and Cercone 1995).

Distributions of three categories of public healthcare-hospital inpatient care, hospital outpatient care, and nonhospital care-are examined.

1. In Latin America cash transfers are increasingly used to affect the distribution of income, as well as that of health and education services, but this is less so in the low-income economies of Asia, where in-kind transfers, such as healthcare, continue to predominate.

2. The equivalence scale used is $e_{b}=\left(A_{b}+0.5 K_{b}\right)^{0.75}$, where $A_{b}$ is the number of adults in household $h$, and $K_{b}$ is the number of children $0-14$ years old. Parameter values were set on the basis of estimates summarized in Deaton (1997, pp. 241-70). 
Nonhospital care is an aggregate of visits to doctors, polyclinics, health centers, and antenatal care (table S-2). For inpatient care the recall period is 12 months, except in Bangladesh (3 months) and Sri Lanka (2 weeks). For all other care the recall period is generally 2 weeks to 1 month, except in Bangladesh where it is 3 months.

Use data do not capture variations in the quality of services received across facilities and geographic locations. This is a potentially important deficiency given evidence of marked quality differences favoring richer neighborhoods even within a single city, such as Delhi, India (Das and Hammer 2005). The service-specific non-negative public subsidy received by an individual can be defined as:

$$
S_{k i}=\max \left(0, q_{k i} c_{k j}-f_{k i}\right)
$$

where $q_{k i}$ is the quantity of service $k$ used by individual $i, c_{k j}$ is the unit cost of providing $k$ in region $j$ where $i$ resides, and $f_{k i}$ is the amount paid for $k$ by $i$. Where possible, variations in costs by facility (local, district, teaching hospital) and service (inpatient/outpatient) are taken into account. Unit costs are computed as:

$$
c_{k j}=\frac{\operatorname{TRE}_{k j}}{\sum_{i \in j} q_{k i} w_{i}}
$$

where $\mathrm{TRE}_{k j}$ is total recurrent public expenditure and $w_{i}$ is an expansion factor that inflates sample use to population use. The total public subsidy received by an individual is computed as $S_{i}=\sum_{k} \alpha_{k} S_{k i}$, where the $\alpha_{k}$ terms are scaling factors that standardize use recall periods across services.

National health accounts, available for Bangladesh, the Chinese provinces, Hong Kong SAR, Sri Lanka, and Thailand, are used to disaggregate expenditure figures by facility, service, and region. Full accounts are not available for India, Indonesia, Malaysia, Nepal, and Vietnam. For India unit subsidies computed for another benefit incidence study are used (Mahal and others 2000). These are specific to 960 subgroups (three facilities, 16 major states, urban-rural residence, gender, and five income quintiles). For Indonesia public health expenditure review figures allow expenditures to be disaggregated for each of 30 provinces. For Malaysia expenditure data were disaggregated to five levels of public hospital care, but geographic disaggregation was not undertaken since the use data could not be analyzed by this dimension. Incomplete health accounts for Nepal allow disaggregation by hospital and nonhospital care by region. For Vietnam public accounts and hospital costing estimates were used to compute unit costs by service and facility but not by region (World Bank 2001).

Subtraction of the user payment from equation (1) to get the net benefit of the service is appropriate provided that quality is not responsive to the 
payment. This is an untestable assumption with the available data. For China, India, Indonesia, Malaysia, Nepal, and Sri Lanka either the survey data do not contain information on payments made by individuals for public health services or the data are not considered sufficiently reliable, for example, because payments for public and other care are likely to be confused. For these countries it is assumed that all users in a particular region pay the same charge for a given service. Waiting and travel time also reduce the net benefit from care and should, in principle, be valued and subtracted in computing the subsidy. The survey data do not permit this, however. As a consequence, benefits to the rural poor, in particular, may be overstated to the extent that they travel long distances to access better quality care. By contrast, the cost of waiting time will be less for the poor if time is valued according to wage rates.

The incidence of public healthcare is described by its concentration curve, which plots the cumulative proportion of healthcare use and subsidy against the cumulative proportion of the population ranked by household consumption per adult equivalent. To establish whether the subsidy is propoor, in the sense that lower income individuals receive more of the subsidy than the better-off, a test is conducted of whether the concentration curve dominates (lies above) the $45^{\circ}$ line. Whether the poorest 20 percent of individuals consume more than 20 percent of healthcare is also tested. Dominance of the concentration curve over the Lorenz curve of household consumption is tested to establish whether spending on public healthcare reduces inequality.

For the dominance tests standard errors of the ordinates of curves and of differences in ordinates are computed, allowing for dependence between curves where appropriate (Bishop, Chow, and Formby 1994; Davidson and Duclos 1997). ${ }^{3}$ A multiple comparison approach to testing is adopted (Beach and Richmond 1985; Bishop, Formby, and Thistle 1992), with the null defined as curves being indistinguishable. This is tested against both dominance and crossing of curves (Dardanoni and Forcina 1999). The null is rejected in favor of dominance if there is at least one significant difference between the ordinates of two curves in one direction and no significant difference in the other direction across 19 evenly spaced quantile points from 0.05 to 0.95 . The null is rejected in favor of crossing if there is at least one significant difference in each direction. The 5 percent level of significance is used with critical values from the studentized maximum modulus distribution to allow for the joint nature of the test (Beach and Richmond 1985). ${ }^{4}$

An alternative dominance test consistent with the intersection-union principle (Kaur, Rao, and Singh 1994; Howes 1996), which has been used in the

3. The computation is carried out in Stata.

4. Dardanoni and Forcina (1999) show that the probability that this test will falsely reject the null in favor of dominance does not exceed the significance level and report Monte Carlo evidence suggesting that the actual significance level is well below its nominal value. 
benefit incidence literature (Sahn and Younger 2000; Sahn, Younger, and Simler 2000), takes nondominance as the null and tests this against the alternative of strict dominance. This is a conservative test that requires statistically significant differences in ordinates at all points of comparison for the null to be rejected. Dardanoni and Forcina (1999) present Monte Carlo evidence showing that while this test reduces the probability of falsely rejecting nondominance to a negligible value, compared with the multiple comparison approach it has greatly reduced power of detecting dominance when true. Given these results, most weight in the discussion below is given to the results from the multiple comparison tests, but discrepancies with the more conservative intersectionunion test are pointed out.

\section{RESULTS}

In Hong Kong SAR, Malaysia, and Thailand the concentration curve of the total public health subsidy dominates both the Lorenz curve and the $45^{\circ}$ line of equality (table 1, final column), indicating that the subsidy is both inequality-reducing and propoor. With the exception of the comparison with the $45^{\circ}$ line in the case of Thailand, these dominance results are robust to use of the stricter test. In Sri Lanka an equal distribution of the total subsidy is not rejected. In relative terms this shifts the distribution of living standards toward the poor, as the concentration curve dominates the Lorenz curve. In the remaining countries and provinces the concentration curve of the total subsidy is dominated by the $45^{\circ}$ line but, with the exceptions of India and Nepal, dominates the Lorenz curve. That is, the subsidy is prorich but inequality reducing. For Bangladesh and the two Chinese provinces nondominance relative to both the Lorenz curve and the $45^{\circ}$ line cannot be rejected when the more conservative intersection-union test is employed. ${ }^{5}$

The degree to which the public health subsidy is targeted to the poor can be seen more explicitly by examining the share of the subsidy received by the poorest 20 percent of individuals (table 2). Public healthcare is clearly most propoor in Hong Kong SAR, with the poorest fifth of the population receiving almost two-fifths of the total subsidy (table 2, final column). In Malaysia the poorest quintile also receives significantly more than 20 percent of the total subsidy, but the propoor bias is much less than it is in Hong Kong SAR. In Sri Lanka and Thailand the poorest quintile's share of the total subsidy does not differ significantly from 20 percent. In the remainder of countries and provinces, with the exception of Bangladesh, the poorest 20 percent of individuals receive significantly less than 20 percent of the public health subsidy. The share going to the poorest 20 percent of individuals is lowest in Nepal, at less than 7 percent, followed by the two Chinese provinces, at $8-10$ percent. In these

5. Concentration and Kakwani indices, which provide summary measures of the magnitude by which the concentration curve deviates from the $45^{\circ}$ line and the Lorenz curve, are given in table S-3. 
Table 1. Tests of Dominance of Concentration Curves for Public Health Service Use and Subsidy against the Lorenz Curve and the 45 Degree Line of Equality

\begin{tabular}{|c|c|c|c|c|c|c|c|c|c|c|c|c|c|c|}
\hline \multirow[b]{3}{*}{ Country, province, or region } & \multicolumn{6}{|c|}{ Use } & \multicolumn{8}{|c|}{ Subsidy } \\
\hline & \multicolumn{2}{|c|}{$\begin{array}{l}\text { Hospital } \\
\text { inpatient }\end{array}$} & \multicolumn{2}{|c|}{$\begin{array}{c}\text { Hospital } \\
\text { outpatient }\end{array}$} & \multicolumn{2}{|c|}{ Nonhospital } & \multicolumn{2}{|c|}{$\begin{array}{l}\text { Hospital } \\
\text { inpatient }\end{array}$} & \multicolumn{2}{|c|}{$\begin{array}{l}\text { Hospital } \\
\text { outpatient }\end{array}$} & \multicolumn{2}{|c|}{ Nonhospital } & \multicolumn{2}{|c|}{ Total } \\
\hline & Lorenz & $45^{\circ}$ & Lorenz & $45^{\circ}$ & Lorenz & $45^{\circ}$ & Lorenz & $45^{\circ}$ & Lorenz & $45^{\circ}$ & Lorenz & $45^{\circ}$ & Lorenz & $45^{\circ}$ \\
\hline Bangladesh & & - & + & - & + & & & & + & - & + & & + & - \\
\hline Gansu, China & + & $-*$ & $+^{*}$ & - & n.a. & n.a. & + & - & + & - & n.a. & n.a. & + & - \\
\hline Hong Kong SAR & $+^{*}$ & $+^{*}$ & $t^{*}$ & $t^{*}$ & $t^{*}$ & $+^{*}$ & $t^{*}$ & $t^{*}$ & $t^{*}$ & $+^{*}$ & $+^{*}$ & $t^{*}$ & $+^{*}$ & $+^{*}$ \\
\hline India & & $-*$ & $+*$ & $-*$ & $+^{*}$ & + & & $-*$ & $t^{*}$ & & $+*$ & $+^{*}$ & & $-*$ \\
\hline Indonesia & - & -* & $\mathrm{x}$ & $-*$ & $+^{*}$ & + & -* & -* & - & -* & $+^{*}$ & + & $+^{*}$ & -* \\
\hline Malaysia & $t^{*}$ & + & $+*$ & & $+^{*}$ & $+^{*}$ & $+^{*}$ & + & $+^{*}$ & & $+^{*}$ & $t^{*}$ & $+^{*}$ & $+^{*}$ \\
\hline Nepal $^{\mathrm{a}}$ & + & -* & n.a. & n.a. & $t^{*}$ & & - & -* & n.a. & n.a. & $\mathrm{x}$ & -* & $\mathrm{x}$ & -* \\
\hline Sri Lanka & $+^{*}$ & & $+^{*}$ & + & $+^{*}$ & & $+*$ & & $+^{*}$ & & n.a. & n.a. & $+^{*}$ & \\
\hline Thailand & $t^{*}$ & & $t^{*}$ & $\mathrm{x}$ & $+*$ & $+*$ & $+^{*}$ & & $+*$ & + & $+*$ & $t^{*}$ & $t^{*}$ & + \\
\hline Vietnam & + & -* & & -* & $+^{*}$ & + & $t^{*}$ & - & + & -* & $+^{*}$ & + & $+^{*}$ & - \\
\hline
\end{tabular}

Blank cell indicates failure to reject the null hypothesis that curves are indistinguishable using the multiple comparison test (Bishop, Formby, and

Thistle 1992) at the 5 percent significance level.

$\mathrm{x}$ indicates rejection of the null hypothesis that curves are indistinguishable in favor of curves crossing using the same test.

$+I-$ indicates rejection of the same null hypothesis in favor of dominance using the same test. A + indicates that healthcare is more concentrated on the poor than is household consumption per adult (Lorenz) or equal per capita distribution $\left(45^{\circ}\right)$, while a - indicates that it is less concentrated.

*indicates rejection of the null hypothesis of nondominance in favor of an alternative of strict dominance using the intersection-union test (Howes

1996) and a 5 percent significance level. Dominance is in the direction indicated by the + or - , as above.

n.a. means that data were not available to conduct the test.

${ }^{a}$ The results in the hospital inpatient columns refer to both inpatient and outpatient.

Source: Authors' calculations based on survey data documented in table S.1 (see supplemental appendix available at http://wber.oxfordjournals.org/). 
Table 2. Share of Total Household Consumption and Public Healthcare Subsidy Received by Poorest Quintile of Individuals (percent)

\begin{tabular}{|c|c|c|c|c|c|}
\hline \multirow{2}{*}{$\begin{array}{l}\text { Country, province, } \\
\text { or region }\end{array}$} & \multirow{2}{*}{$\begin{array}{l}\text { Household consumption } \\
\text { per adult equivalent }\end{array}$} & \multicolumn{2}{|c|}{ Hospital care } & \multirow[b]{2}{*}{ Nonhospital care } & \multirow[b]{2}{*}{ Total subsidy } \\
\hline & & Inpatient & Outpatient & & \\
\hline Bangladesh & $7.25 *(0.0437)$ & $15.20(6.3732)$ & $11.60 *(1.8853)$ & $24.42(5.5695)$ & $16.78(3.4916)$ \\
\hline Gansu, China $^{a}$ & $5.24 *(0.0695)$ & $7.27 *(1.5331)$ & $9.57 *(1.6473)$ & n.a. & $8.17 *(1.2265)$ \\
\hline Heilongjiang, China ${ }^{a}$ & $5.98 *(0.0759)$ & $6.57 *(1.8184)$ & $12.32 *(2.5677)$ & n.a. & $10.47 *(1.8729)$ \\
\hline Hong Kong SAR & $6.82 *(0.0377)$ & $38.77 *(3.2580)$ & $38.68 *(2.2048)$ & $38.19 *(1.7718)$ & $38.73 *(2.7463)$ \\
\hline India & $10.50 *(0.0083)$ & $10.70 *(1.1086)$ & $18.59(1.6219)$ & $26.23 *(1.5471)$ & $12.49 *(0.9553)$ \\
\hline Indonesia & $9.77 *(0.0078)$ & $3.80 *(0.3762)$ & $5.77 *(0.4857)$ & $19.73(0.3199)$ & $13.46 *(0.2582)$ \\
\hline Malaysia & $7.20 *(0.0370)$ & $21.19(0.8807)$ & $18.72(1.1208)$ & $32.25 *(1.3422)$ & $22.95 *(0.6921)$ \\
\hline Nepal $^{\mathrm{b}}$ & $8.05 *(0.0534)$ & $3.52 *(1.4851)$ & $3.52 *(1.4851)$ & $9.04 *(1.7220)$ & $6.64 *(1.1780)$ \\
\hline Sri Lanka ${ }^{c}$ & $8.31 *(0.0725)$ & $20.76(2.6013)$ & $21.11(1.9418)$ & n.a. & $20.88(1.8367)$ \\
\hline Thailand & $6.94 *(0.0589)$ & $21.26(1.4144)$ & $17.70 *(1.0278)$ & $31.16 *(1.9137)$ & $20.06(0.8963)$ \\
\hline Vietnam & $8.78 *(0.0429)$ & $13.64 *(1.9209)$ & $11.55 *(1.7049)$ & $19.73(1.7346)$ & $14.79 *(1.5416)$ \\
\hline
\end{tabular}

*Significantly different from 20 percent at the 5 percent significance level. Bold indicates that the subsidy share is significantly different from the household consumption share.

n.a. means that data were not available to conduct the test.

Note: Numbers in parentheses are standard errors.

${ }^{\text {a }}$ There are no data on nonhospital care, but low-level hospitals, equivalent to polyclinics and health centers, are included.

${ }^{\mathrm{b}}$ It is not possible to distinguish between hospital inpatient and outpatient visits.

'The subsidy specific to nonhospital care cannot be computed.

Source: Authors' calculations based on data documented in table S.1 (see supplemental appendix available at http://wber.oxfordjournals.org/). 
cases, and in Bangladesh, India, and Indonesia, the richest quintile receives more than 30 percent of the total subsidy (not shown in table). In all cases but Nepal the share of the subsidy going to the poorest quintile is significantly greater than its share of total household consumption.

\section{Differences in Incidence across Health Services}

Only in Hong Kong SAR does the concentration curve dominate the $45^{\circ}$ line for both hospital inpatient and outpatient care and for nonhospital care (see table 1), with the poorest quintile receiving about 39 percent of the subsidy to all three services (see table 2). In Malaysia the concentration curves for inpatient and nonhospital care lie above the $45^{\circ}$ line, but the outpatient care curve does not deviate significantly from the line of equality (see table 1 ). In Thailand it is inpatient care that is equally distributed, while the concentration curves for the other types of care dominate the diagonal, at least using the less stringent test criteria. However, in both Malaysia and Thailand the poorest quintile receives significantly more than 20 percent of the subsidy only for nonhospital care (see table 2). In Sri Lanka there is equality in the distributions of all services except for a propoor distribution of outpatient care as measured by use (see table 1). In the remainder of countries and provinces, concentration curves for hospital care tend to lie below the diagonal-meaning that the better-off consume more-while the curves for nonhospital care lie above it. The poorest quintile fairly consistently receives less than 20 percent of the subsidy for hospital care and significantly more than 20 percent of the subsidy for nonhospital care only in India (see table 2).

For most countries and provinces the distribution of nonhospital care dominates that of hospital inpatient and outpatient care (table 3), confirming that nonhospital care is generally more targeted to the poor than is hospital care.

\section{Comparison of Use and Subsidy Distributions}

Estimating the incidence of the public healthcare subsidy requires much more information than that of raw use. Unit costs must be estimated at the facility and regional levels and, where appropriate and possible, fees paid by individuals must be identified. The effort involved to obtain this extra information is worthwhile only if there is significant variation in unit costs or fees with the indicator of household living standards and if this covariance is sufficiently large relative to that for use. The dominance tests reported in table 1 display a considerable consistency across the use and subsidy measures. Only in 10 of 58 pairwise comparisons do the conclusions of the test differ depending on whether the distribution of use or the subsidy is examined. This is not an insubstantial degree of disagreement, but it suggests that the results of dominance tests are generally robust to the measure over which incidence is examined and that variation in use, not unit subsidies, is the main driver of the public subsidy distribution. This increases the confidence that can be placed in studies that look only at use. It is consistent with the findings of Sahn and 
Taвle 3. Tests of Dominance between Concentration Curves for Different Public Health Services and between Use and Subsidy Distributions

\begin{tabular}{|c|c|c|c|c|c|c|}
\hline \multirow[b]{2}{*}{$\begin{array}{l}\text { Country, province, } \\
\text { or region }\end{array}$} & \multicolumn{3}{|c|}{ Use } & \multicolumn{3}{|c|}{ Use and subsidy } \\
\hline & $\begin{array}{l}\text { Hospital inpatient } \\
\text { versus outpatient }\end{array}$ & $\begin{array}{l}\text { Hospital inpatient } \\
\text { versus nonhospital }\end{array}$ & $\begin{array}{l}\text { Hospital outpatient } \\
\text { versus nonhospital }\end{array}$ & $\begin{array}{l}\text { Hospital } \\
\text { inpatient }\end{array}$ & $\begin{array}{l}\text { Hospital } \\
\text { outpatient }\end{array}$ & Nonhospital \\
\hline Bangladesh & $o p>i p$ & & & & & \\
\hline Gansu, China & op $>$ ip $*$ & n.a. & n.a. & & use $>$ subsidy & n.a. \\
\hline $\begin{array}{l}\text { Heilongjiang, China } \\
\text { Hong Kong SAR }\end{array}$ & op >ip & n.a. & n.a. & & & $\begin{array}{l}\text { n.a. } \\
\text { use }>\text { subsidy }\end{array}$ \\
\hline India & op $>$ ip $*$ & non-h>ip* & non-h>op* & & subsidy $>$ use & subsidy $>$ use \\
\hline Indonesia & op $>$ ip & non-h>ip* & non-h>op & use $>$ subsidy* & use $>$ subsidy* & use $>$ subsidy \\
\hline Malaysia & & non-h>ip & non-h>op & use $>$ subsidy* & use $>$ subsidy* & n.a. \\
\hline Nepal & & non-h $>(\text { ip }+o p)^{a}$ & non-h $>(\text { ip }+o p)^{a}$ & & & use $>$ subsidy \\
\hline Sri Lanka & & & op $>$ non-h & use $>$ subsidy & use $>$ subsidy & n.a. \\
\hline Thailand & & non-h $>$ ip & non-h>op* & & & subsidy $>$ use \\
\hline Vietnam & & non-h>ip* & non-h>op* & subsidy $>$ use $*$ & & \\
\hline
\end{tabular}

ip is inpatient, op is outpatient, non-h is non hospital.

Blank cell indicates failure to reject the null hypothesis that curves are indistinguishable using the multiple comparison test at the 5 percent significance level.

$>$ indicates that the null hypothesis is rejected in favor of dominance, for example, op $>$ ip indicates that outpatient care is more propoor than inpaticare and use $>$ subsidy indicates that the use distribution is more propoor than the subsidy distribution.

*indicates rejection of the null hypothesis of nondominance in favor of an alternative strict dominance in the direction indicated by $>$, as above, using the intersection-union test and a 5 percent significance level.

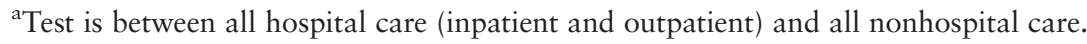

Source: Authors' calculations based on survey data documented in table S.1 (see supplemental appendix S.1 available at http://wber.oxfordjournals. org/). 
Younger (2000) but somewhat stronger, since the current study allows for more sources of heterogeneity in unit subsidies.

Notwithstanding this result, there are significant differences between the distributions of use and subsidy. In Indonesia, Malaysia, and Sri Lanka the use distributions dominate-they are more propoor than the subsidy distributions-for all services, and in Gansu, Hong Kong SAR, and Nepal this is true for some services (see table 3). Dominance is not always found using the more conservative test, however. Urban-rural and regional differences in the quality of care are the most likely reason that the subsidy is less propoor than use. Only in India, Thailand, and Vietnam does the subsidy distribution dominate the use distribution for certain services, indicating that the subsidy per unit of care falls as household consumption rises. This is likely due to user payments rising with household consumption, whether because of exemptions granted to the poor or because richer households are paying for higher quality care that is not reflected in the unit cost figures.

\section{Cross-Country Comparisons}

As would be expected from the results already presented, the subsidy concentration curve of Hong Kong SAR dominates that of all other countries and provinces (table 4). ${ }^{6}$ The incidence of public care is so skewed toward the poor that the distribution of total healthcare (public and private) in Hong Kong SAR is propoor (Leung, Tin, and O'Donnell 2005). ${ }^{7}$ While this is in striking contrast with the distribution of healthcare in the low- and middle-income countries examined in this article, it is consistent with the distribution that prevails in most high-income economies (Van Doorslaer, Masseria, and Koolman 2006).

There are no significant differences between the concentration curves of Malaysia, Sri Lanka, and Thailand, where the subsidies range from slightly propoor to evenly distributed. On the less strict test the Vietnamese distribution is dominated by that of Hong Kong SAR, Malaysia, and Thailand and it is indistinguishable from that of Sri Lanka. It dominates the subsidy distributions of all the remaining countries and provinces using the less stringent test. ${ }^{8}$ For most pairwise comparisons the subsidy concentration curves of Bangladesh, Gansu, Heilongjing, India, Indonesia, and Nepal are indistinguishable. Exceptions are that India and Indonesia dominate Gansu and Nepal using the less strict test. In all these countries and provinces the public health subsidy is significantly and substantially prorich (see tables 1 and 2). This is

6. See table S-4 for cross-country dominance tests for each type of health service subsidy.

7. Some 43.5 percent of total expenditure on health in Hong Kong SAR is funded from private sources (Hong Kong Domestic Health Accounts 1999-2000).

8. This is not due simply to the fact that unit subsidies are negatively correlated with household consumption in Vietnam, unlike in most other countries and provinces. Only one cross-country dominance result for Vietnam becomes insignificant when use of each service rather than the subsidy to each service is examined. 
Table 4. Cross-Country Dominance of Public Health Subsidy Concentration Curves

\begin{tabular}{|c|c|c|c|c|c|c|c|c|c|c|}
\hline & Malaysia & Thailand & Sri Lanka & Vietnam & Bangladesh & Indonesia & India & Gansu & Heilongjiang & Nepal \\
\hline Hong Kong SAR & $D^{*}$ & $\mathrm{D}^{*}$ & $\mathrm{D}^{*}$ & $\mathrm{D}$ & $\mathrm{D}^{*}$ & $\mathrm{D}^{*}$ & $D^{*}$ & $D^{*}$ & $D^{*}$ & $\mathrm{D}^{*}$ \\
\hline Malaysia & & n.s. & n.s. & $\mathrm{D}$ & $\mathrm{D}$ & $\mathrm{D}^{*}$ & $D^{*}$ & $D^{*}$ & $\mathrm{D}^{*}$ & $D^{*}$ \\
\hline Thailand & & & n.s. & $\mathrm{D}$ & $\mathrm{D}$ & $D^{*}$ & $D^{*}$ & $\mathrm{D}$ & $D^{*}$ & $D^{*}$ \\
\hline Sri Lanka & & & & n.s. & ns & $\mathrm{D}$ & $\mathrm{D}$ & $\mathrm{D}$ & $\mathrm{D}^{*}$ & $D^{*}$ \\
\hline Vietnam & & & & & $\mathrm{D}$ & $D^{*}$ & $\mathrm{D}$ & $D^{*}$ & $\mathrm{D}$ & $D^{*}$ \\
\hline Bangladesh & & & & & & ns & ns & ns & ns & ns \\
\hline Indonesia & & & & & & & ns & $\mathrm{D}$ & ns & $\mathrm{D}$ \\
\hline India & & & & & & & & $\mathrm{D}$ & ns & $\mathrm{D}$ \\
\hline Gansu, China & & & & & & & & & ns & ns \\
\hline Heilongjiang, China & & & & & & & & & & ns \\
\hline
\end{tabular}

n.s. indicates failure to reject the null hypothesis that the curves are indistinguishable using the multiple comparison test at the 5 percent significance level.

D indicates rejection of the null in favor of dominance (more propoor) of the row country over the column country by the same test.

*indicates that the intersection-union test rejects the null of nondominance against the alternative of strict dominance at the 5 percent significance level.

Source: Authors' calculations based on survey data documented in table S.1 (see supplemental appendix available at http://wber.oxfordjournals.org/). 
consistent with the findings of the majority of benefit incidence studies conducted in developing countries (van de Walle 1995; Castro-Leal and others 2000; Mahal and others 2000; Sahn and Younger 2000; Filmer 2003). But Malaysia, Thailand, Sri Lanka, and to a lesser extent Vietnam stand out as exceptions to this norm of prorich bias. Why is it that public healthcare is more propoor in these four countries than it is in other developing countries of Asia and elsewhere?

National income is an obvious candidate to explain cross-country variation in the targeting of public health spending. Public healthcare is strongly targeted to the poor in Hong Kong SAR in large part because Hong Kong is rich enough to afford a dual system of universal public healthcare funded from general taxation and a private healthcare system used predominantly by the better-off to bypass the bottlenecks and inconveniences of the public system. It is surely no coincidence that Malaysia and Thailand are the only other two countries where public health spending is significantly propoor. While they are not nearly as rich as Hong Kong SAR, they are considerably better off than the other countries included in this study (see table S-5).

Economic development is not the sole explanation for cross-country differences in the incidence of public healthcare. It does not explain why Sri Lanka, despite a lower GDP per capita than Indonesia, achieves a distribution of health resources that is much more favorable to the poor. Levels of public spending on health and health system characteristics might be expected to explain part of the residual cross-country variation in targeting of the poor. In per capita terms Sri Lanka spends 2.5 times as much as Indonesia on public healthcare (table S-5). The scale of public spending may influence its incidence by affording a wider geographic distribution of public health facilities and so bring services closer to poor, rural populations.

There may also be a trickle-down effect. At low levels of spending the politically powerful, higher income urban elite may be more successful than the rural poor in capturing spending for programs that meet their own needs. As spending levels rise and more of the health needs of higher income groups are satisfied, additional programs can be better targeted to the needs of the poor (Lanjouw and Ravallion 1999). Countering this tendency, the pressure from higher income groups for prioritization of tertiary-level city hospitals may be maintained by the attraction of continuing advances in medical technology (Victora and others 2000).

The extent to which higher income groups claim the benefits from public healthcare will depend on whether an attractive private sector alternative exists. Income-elastic demand for healthcare quality, in particular amenities and convenience of service, will lead to greater substitution of private for public care by an expanding middle-class as the economy grows. Hammer, $\mathrm{Nabi}$, and Cercone (1995) argue that this mechanism was largely responsible for the increased propoor incidence of public health spending in Malaysia between the mid-1970s and the mid-1980s. The private sector continues to 
grow in Malaysia, driven in part by dissatisfaction with the responsiveness of the public system (Shepard, Savedoff, and Phua 2002). In Thailand, which has also achieved impressive economic growth in recent years, the private sector is also expanding rapidly (Towse, Mills, and Tangcharoensathien 2004).

The combination of (near) universal public provision, a private sector offering an attractive alternative, and incomes that make demand for this alternative effective leads to redistribution through public provision in the way that theory predicts (Besley and Coate 1991). This mechanism implies a possibly uncomfortable tradeoff between the quality of public healthcare and the extent to which it is targeted to the poor. In lower income countries, such as Bangladesh, India, and Indonesia, separation of low- and highincome groups into the public and private sectors is constrained not only by the limited purchasing power of the middle class but also by marked intrasectoral quality differentials. There is evidence of pronounced income gradients in the quality of private sector care used in India (Das and Hammer 2005). There, as in Bangladesh, the poor make extensive use of unqualified private providers.

This discussion suggests that economic development, the scale of public health spending, and the availability and quality of private sector alternatives may each help explain cross-country variation in the incidence of public health spending. Regression analysis is used to examine whether this is the case across the study countries and provinces and others for which benefit incidence results are available from other studies (Filmer 2003). Only 24 observations are available for this analysis, and so the results (table 5) should be treated with due caution. It is an exploratory exercise and not an empirical test of hypotheses. The dependent variable is the $(\log )$ percentage of the total public subsidy received by the poorest quintile. This share increases significantly with GDP per capita, with an elasticity of about 0.3 . At a lower level of significance (10 percent), the poorest quintile's share is also increasing with public health spending as a percentage of GDP, with an elasticity of about 0.5 . So, for a given GDP there is some evidence that the share of the subsidy going to the poor is increasing with the scale of public health spending.

To examine whether, for a given level of public expenditure, the share of the subsidy going to the poor increases with use of private sector alternatives, public spending as a percentage of total expenditure on health is included in the regression. Consistent with the hypothesis, the coefficient is negative but does not reach conventional levels of significance. The regression residuals are largest, in absolute value, for the two Chinese provinces. Public health spending in these provinces is much less targeted on the poor than would be expected given GDP and the scale of public spending and its share of total health financing. This is most likely due to the extensive imposition of user charges with no income-related exemptions. Excluding these two provinces increases the magnitude and significance of the coefficients. In particular, the 
Table 5. Cross-Country Regression Analysis of Targeting of the Public Health Subsidy (Dependent variable: log of percentage of public health subsidy received by poorest quintile)

\begin{tabular}{|c|c|c|c|c|}
\hline & \multicolumn{2}{|c|}{ Full sample } & \multicolumn{2}{|c|}{$\begin{array}{l}\text { Excluding Gansu and } \\
\text { Heilongjiang }\end{array}$} \\
\hline & Coefficient & $\begin{array}{l}\text { Robust standard } \\
\text { error }^{\mathrm{a}}\end{array}$ & Coefficient & $\begin{array}{c}\text { Robust standard } \\
\text { error }^{\mathrm{a}}\end{array}$ \\
\hline Log of gdp per capitab & $0.3214 * * *$ & 0.1002 & $0.3426 * *$ & 0.0889 \\
\hline $\begin{array}{l}\text { Public health expenditure } \\
\text { as percent of gdp }\end{array}$ & $0.2337^{*}$ & 0.1190 & $0.2971 * * *$ & 0.0884 \\
\hline $\begin{array}{l}\text { Public health expenditure } \\
\text { as percent of total health } \\
\text { expenditure }\end{array}$ & -0.0080 & 0.0049 & $-0.0110^{* * *}$ & 0.0043 \\
\hline $\begin{array}{l}\text { Eastern Europe and } \\
\text { Central Asia }\end{array}$ & -0.3308 & 0.2091 & $-0.4895^{* *}$ & 0.1889 \\
\hline $\begin{array}{l}\text { Latin America and } \\
\text { Carribean }\end{array}$ & -0.2478 & 0.3535 & -0.4338 & 0.2990 \\
\hline Sub-Saharan Africa & $-0.8630 * * *$ & 0.3004 & $-1.0750 * * *$ & 0.2093 \\
\hline Constant & 0.0691 & 0.7465 & 0.0294 & 0.7118 \\
\hline Sample size & 24 & & 22 & \\
\hline$R^{2}$ & 0.5712 & p-value & 0.7421 & p-value \\
\hline $\operatorname{RESET}\left(\mathrm{F}_{3, \mathrm{n}-\mathrm{k}-3}\right)$ & 0.76 & 0.5371 & 0.71 & 0.5671 \\
\hline
\end{tabular}

"Significant at the 10 percent level; **significant at the 5 percent level; ** significant at the 1 percent level.

Note: Observations are the 11 countries and provinces for the years of this study plus those from Filmer (2003): Armenia (1999) Bangladesh (1995), Bulgaria (1995), Costa Rice (1992), Cote d'Ivoire (1995), Ecuador (1998), Georgia (2000), Ghana (1994), Guinea (1994), Honduras (1995), Nicaragua (1996), South Africa (1994), and Vietnam (1993).

${ }^{\text {a }}$ Robust to heteroscedasticity of general form.

${ }^{\mathrm{b}}$ Gross domestic product per capita in purchasing power parity dollars at constant 2000 prices.

source: Dependent variable, authors' calculations based on data in table S. 1 (see supplemental appendix available at http://wber.oxfordjournals.org/) and that reported in Filmer (2003). GDP, World Bank, various years, World Development Indicators. Health expenditure, WHO, various years, National Health Accounts and World Health Report Statistical Annexes.

negative coefficient on the public health financing share becomes significant at 5 percent. ${ }^{9}$ Although this study has found that the public health subsidy is not targeted on the poor in the majority of the 11 Asian countries and provinces examined, the distribution appears to be even more skewed toward the betteroff in Eastern Europe and Central Asia and in Sub-Saharan Africa. ${ }^{10}$

9. The results are similar if the weight given to observations with large absolute residuals is reduced, but not set to zero, using robust regression. The results are also robust to the exclusion of Hong Kong SAR, where the subsidy is much more propoor and GDP is much higher than in the other countries and provinces.

10. Other potential explanatory factors, including the Gini coefficient, the urbanization rate, and the doctor supply rate, were not found to be significant. 
These regression results tell only of associations in a fairly small sample of countries and should not be interpreted as causal effects. GDP may be acting as a proxy for a number of primary determinants of incidence, such as the quality of governance and preferences for redistribution. Through human capital acquisition, assuming that the marginal product of investments in health is higher for poorer (and sicker) individuals, GDP may itself be responsive to the targeting of healthcare to the poor. Polices are of course endogenous. The positive correlation between the scale and the propoor incidence of public spending may derive from the degree of political commitment to reaching the poor. Reducing racial conflict in post-independence Malaysia was a major motivation for the expansion in access to healthcare and the channeling of public resources to the rural Malay population (Hammer, Nabi, and Cercone 1995). The early adoption of democracy and female suffrage in Sri Lanka contributed to the high priority given to healthcare and the wide geographical distribution of health resources in response to the lobbying of local politicians (McNay, Keith, and Penrose 2004). In fact, a 1928 commission proposed the full enfranchisement of women at the same time as men as a means of securing a political lobby for the prioritization of healthcare (Rannan-Eliya 2001). High rates of female literacy and a relatively high degree of female autonomy have raised awareness of maternal and child health problems, leading to high rates of use of modern health facilities and medicines (Caldwell 1986).

Political and economic circumstances determine the motivation and resources for the pursuit of propoor public healthcare, but realization of the objective depends on the specific health sector policies adopted. One policy has been to minimize charges for poor patients in accessing care. There are virtually no fees for public health services in Sri Lanka, and fees are minimal in both Hong Kong SAR and Malaysia (table S-6). In all three cases fees are not retained by facilities or even by the health sector, but accrue to general revenues, thus undermining providers' incentives for generating fee revenue. The near avoidance of user fees in resource-poor Sri Lanka has been feasible only by driving down unit costs (Rannan-Eliya 2001). Nonmonetary incentives, such as professional development and opportunities to work simultaneously in the private sector, help maintain high levels of staff productivity. In Thailand fees have been much higher. Prior to the introduction of universal coverage in 2001, public hospitals received 20-50 percent of their revenue from user fees (Towse, Mills, and Tangcharoensathien 2004). But the disincentive effect on use by the poor was limited through a fairly effective healthcard scheme that covered about two-thirds of the poor. Crucially, this scheme compensated providers for fee exemptions from a designated budget.

A geographically dispersed network of health facilities close to the rural population also appears to contribute to the propoor targeting of health spending. In Malaysia half the population lives within 10 kilometers of a public 
hospital and within 4.6 kilometers of a public clinic. ${ }^{11}$ In Sri Lanka most of the population has lived within 5 kilometers of a healthcare facility since the early 1970s, and most of the rural population is within 5-10 kilometers of a peripheral facility (Hsiao 2000). In Thailand, although beds and doctors are highly concentrated in Bangkok, an extensive rural infrastructure has been developed over decades. There are primary care health centers in all subdistricts and community hospitals in all districts (Towse, Mills, and Tangcharoensathien 2004). The introduction of universal coverage has initiated a major shift of resources from urban hospitals to primary care. Vietnam also has a relatively high level of provision in rural areas through a comprehensive network of commune health centers.

But the contribution of primary care to propoor public health spending should not be exaggerated. Public health spending is better targeted on the poor in Hong Kong SAR, Malaysia, Thailand, Sri Lanka, and Vietnam because the distribution of hospital care is more favorable to the poor and not because more resources are devoted to nonhospital care (see table S-3). Of course, hospitals differ. In Malaysia and Sri Lanka many hospitals are small in scale and not particularly well equipped. But their wide geographic distribution makes them accessible to the rural poor. In many other low-income countries, such as Bangladesh, resources are more concentrated in large, well-equipped hospitals in urban centers that are inaccessible to the poor.

\section{CONCLUSION}

The analysis reveals substantial variation across Asia in the incidence of public subsidies for healthcare. Public spending is strongly propoor in high-income Hong Kong SAR. The total public health subsidy is more moderately propoor in low- to middle-income Malaysia and Thailand and it is evenly distributed in low-income Sri Lanka. At a still lower level of national income the subsidy is mildly prorich in Vietnam. In the remainder of the low-income countries and provinces examined, which account for the far greater share of the Asian population, the better-off receive substantially more of the subsidy than do the poor. In most cases there is prorich bias in the distribution of hospital care, while nonhospital care is propoor. A greater share of the healthcare subsidy goes to hospital care, and so this dominates the overall distribution. While public health subsidies are typically not propoor, they are inequality reducing in all cases except India and Nepal.

Most within- and between-country dominance tests are robust to whether the distribution of healthcare use or the value of the subsidy is examined. This is a reassuring result since the health accounts data required for analysis of subsidy incidence are often unavailable and raw use data must be relied on. There are, however, significant differences between the distribution of

11. Authors' calculations from the 1996 National Health and Morbidity Survey. 
healthcare use and healthcare subsidies, with use often more propoor. Where this occurs, the likely explanation is urban-rural and interregional differences in the nature and funding of facilities.

The analysis shows that the prorich distribution of public healthcare subsidies that is pervasive in most developing countries is avoidable but that effective targeting is easier to realize at higher levels of national incomes. The experiences of Malaysia, Sri Lanka, Thailand, and Vietnam suggest that achieving a more propoor incidence of public health spending requires limiting the use of user fees, or at least effectively protecting the poor from them; building a wide geographic network of health facilities; and ensuring that hospital care, which absorbs most spending, is sufficiently targeted at the poor. 
Appendix: The Incidence of Public Spending on HealthCare: Comparative Evidence From Asia TABLE S1. Description of sample surveys

\begin{tabular}{|c|c|c|c|c|c|c|c|c|}
\hline Country & $\begin{array}{l}\text { Survey } \\
\text { year }\end{array}$ & $\begin{array}{l}\text { Survey } \\
\text { name }\end{array}$ & $\begin{array}{l}\text { Institution } \\
\text { conducting } \\
\text { survey }\end{array}$ & $\begin{array}{l}\text { Survey } \\
\text { coverage }\end{array}$ & Survey design & $\begin{array}{l}\text { Sampling } \\
\text { unit }\end{array}$ & $\begin{array}{l}\text { Response } \\
\text { rate }\end{array}$ & $\begin{array}{l}\text { Sample size } \\
\text { individuals }\end{array}$ \\
\hline Bangladesh & $\begin{array}{r}1999- \\
2000\end{array}$ & $\begin{array}{l}\text { Health and } \\
\text { Demographic } \\
\text { Survey (HDS) } \\
2000\end{array}$ & $\begin{array}{l}\text { Bangladesh Bureau } \\
\text { of Statistics } \\
\text { (BBS) }\end{array}$ & National & Stratified & $\begin{array}{l}\text { Household and } \\
\text { Individual }\end{array}$ & $99 \%$ & 56,010 \\
\hline $\begin{array}{l}\text { Gansu } \\
\text { (China) }\end{array}$ & 2003 & $\begin{array}{l}\text { National Health } \\
\text { Household } \\
\text { Interview } \\
\text { Surveys }\end{array}$ & Ministry of Health & $\begin{array}{l}\text { Gansu province } \\
\text { (poor in } \\
\text { west China) }\end{array}$ & $\begin{array}{l}\text { Stratified, cluster } \\
\text { sample. Self- } \\
\text { weighting }\end{array}$ & Household & $100 \%$ & 15,535 \\
\hline $\begin{array}{l}\text { Heilongjiang } \\
\text { (China) }\end{array}$ & 2003 & $\begin{array}{l}\text { Heilongjiang } \\
\text { Health } \\
\text { Household } \\
\text { Interview Survey }\end{array}$ & $\begin{array}{l}\text { Health bureau of } \\
\text { Heilongjiang } \\
\text { province }\end{array}$ & $\begin{array}{l}\text { Heilongjiang } \\
\text { province } \\
\text { (north-east } \\
\text { China) }\end{array}$ & $\begin{array}{l}\text { Stratified, cluster } \\
\text { sample. Self- } \\
\text { weighting }\end{array}$ & Household & $100 \%$ & 11,572 \\
\hline $\begin{array}{l}\text { Hong Kong } \\
\text { SAR }\end{array}$ & $\begin{array}{l}\text { April- } \\
\text { June } \\
2002\end{array}$ & $\begin{array}{l}\text { Thematic } \\
\text { Household } \\
\text { Survey in the } \\
\text { second quarter } \\
\text { of } 2002\end{array}$ & $\begin{array}{l}\text { Census and } \\
\text { Statistics } \\
\text { Department, } \\
\text { Government of } \\
\text { Hong Kong } \\
\text { SAR }\end{array}$ & National & $\begin{array}{l}\text { Stratified. } \\
\text { Sample } \\
\text { weights } \\
\text { applied }\end{array}$ & $\begin{array}{l}\text { Household } \\
\text { (noninstitutional; } \\
\text { individual } \\
\text { (institutional) }\end{array}$ & $\begin{array}{l}78.4 \% \\
\quad \text { (noninstitutional); } \\
97.2 \% \\
\text { (institutional) }\end{array}$ & 31,672 \\
\hline India & $1995-96$ & $\begin{array}{l}\text { National Sample } \\
\text { Survey 52nd } \\
\text { round }\end{array}$ & $\begin{array}{l}\text { National Sample } \\
\text { Survey } \\
\text { Organisation }\end{array}$ & National & $\begin{array}{l}\text { Stratified, cluster } \\
\text { sample. } \\
\text { Weights } \\
\text { applied }\end{array}$ & Household & $100 \%$ & 629,024 \\
\hline Indonesia & 2001 & $\begin{array}{l}\text { Socioeconomic } \\
\quad \text { Survey } \\
\text { (SUSENAS) }\end{array}$ & $\begin{array}{l}\text { National Board of } \\
\text { Statistics }\end{array}$ & National & $\begin{array}{l}\text { Stratified, cluster } \\
\text { sampling. Self- } \\
\text { weighted }\end{array}$ & Household & $98 \%$ & 889,413 \\
\hline
\end{tabular}


TABle S1. Continued

\begin{tabular}{|c|c|c|c|c|c|c|c|c|}
\hline Country & $\begin{array}{l}\text { Survey } \\
\text { year }\end{array}$ & $\begin{array}{c}\text { Survey } \\
\text { name }\end{array}$ & $\begin{array}{l}\text { Institution } \\
\text { conducting } \\
\text { survey }\end{array}$ & $\begin{array}{l}\text { Survey } \\
\text { coverage }\end{array}$ & Survey design & $\begin{array}{l}\text { Sampling } \\
\text { unit }\end{array}$ & $\begin{array}{l}\text { Response } \\
\text { rate }\end{array}$ & $\begin{array}{l}\text { Sample size } \\
\text { individuals }\end{array}$ \\
\hline Malaysia & 1996 & $\begin{array}{l}\text { National Health } \\
\text { and Morbidity } \\
\text { Survey II }\end{array}$ & $\begin{array}{l}\text { Public Health } \\
\text { Institute, } \\
\text { Ministry of } \\
\text { Health }\end{array}$ & National & $\begin{array}{l}\text { Stratified, cluster } \\
\text { sample. } \\
\text { Weights } \\
\text { applied }\end{array}$ & Household & $86.90 \%$ & 59,903 \\
\hline Nepal & $1995 / 96$ & $\begin{array}{l}\text { Nepal Living } \\
\text { Standards } \\
\text { Survey }\end{array}$ & $\begin{array}{c}\text { Central Bureau of } \\
\text { Statistics (CBS) }\end{array}$ & National & $\begin{array}{l}\text { Stratified, cluster } \\
\text { sample. } \\
\text { Weights } \\
\text { applied }\end{array}$ & Household & $96.60 \%$ & 18,855 \\
\hline Sri Lanka & $1996 / 97$ & $\begin{array}{l}\text { Consumer Finance } \\
\text { Survey }\end{array}$ & Central Bank & $\begin{array}{l}\text { Excluded } \\
\text { Northern } \\
\text { Province due } \\
\text { to civil war. }\end{array}$ & Stratified & Household & $98 \%$ & 399,28 \\
\hline Thailand & $\begin{array}{l}\text { Jan-June } \\
2002\end{array}$ & $\begin{array}{l}\text { Socioeconomic } \\
\text { Survey }\end{array}$ & $\begin{array}{l}\text { National Statistical } \\
\text { Office }\end{array}$ & National & Stratified & Household & $80 \%$ & 17,489 \\
\hline Vietnam & 1998 & $\begin{array}{l}\text { Living Standards } \\
\quad \text { Survey }\end{array}$ & $\begin{array}{l}\text { General Statistical } \\
\text { Office }\end{array}$ & National & $\begin{array}{l}\text { Stratified, cluster } \\
\text { sample. } \\
\text { Weights } \\
\text { applied }\end{array}$ & Household & $70 \%$ & 28,623 \\
\hline
\end{tabular}


TABLE S2. Measures of healthcare utilisation

\begin{tabular}{|c|c|c|c|c|c|c|}
\hline & \multicolumn{2}{|c|}{ Hospital care } & \multirow[b]{2}{*}{ Doctor visits } & \multirow{2}{*}{$\begin{array}{l}\text { Nonhospital care } \\
\text { Polyclinic/health } \\
\text { center }\end{array}$} & \multirow[b]{2}{*}{ Antenatal care } & \multirow[b]{2}{*}{ Comments } \\
\hline & Inpatients & outpatients & & & & \\
\hline \multicolumn{7}{|l|}{ Bangladesh } \\
\hline Reference period & \multicolumn{2}{|c|}{ last episode in previous 3 months } & \multicolumn{2}{|c|}{ last episode in previous 3 months } & \multirow{2}{*}{3 months } & \multirow{2}{*}{$\begin{array}{l}\text { Care at satellite and community } \\
\text { clinics also included but not } \\
\text { child immunisation }\end{array}$} \\
\hline Measurement unit & Number of days & $\begin{array}{l}\text { Number of } \\
\text { visits }\end{array}$ & $\begin{array}{l}\text { Number of } \\
\text { visits }\end{array}$ & & & \\
\hline \multicolumn{7}{|c|}{ Gansu and Heilongjiang (China) } \\
\hline Measurement unit & Number of days & $\begin{array}{l}\text { Number of } \\
\text { visits }\end{array}$ & $\begin{array}{l}\text { Number of } \\
\text { visits }\end{array}$ & 2 weeks & n.a. & $\begin{array}{l}\text { Data on hospital care only. Five } \\
\text { levels of hospital are } \\
\text { distinguished, the lowest of } \\
\text { which are equivalent to } \\
\text { polyclinics. }\end{array}$ \\
\hline \multicolumn{7}{|l|}{ Hong Kong SAR } \\
\hline Reference period & 12 months & 30 days & 30 days & \multirow[t]{2}{*}{ n.a. } & \multirow[t]{2}{*}{ n.a. } & \multirow{2}{*}{$\begin{array}{l}\text { Hospital outpatient includes } \\
\text { visits to specialist and A\&E. } \\
\text { Doctor visits is general } \\
\text { outpatient visits. }\end{array}$} \\
\hline Measurement unit & Number of days & $\begin{array}{l}\text { Number of } \\
\text { visits }\end{array}$ & $\begin{array}{l}\text { Number of } \\
\text { visits }\end{array}$ & & & \\
\hline \multicolumn{7}{|l|}{ India } \\
\hline Reference period & 12 months & 2 weeks & \multirow[t]{3}{*}{2 weeks } & \multirow{3}{*}{$\begin{array}{l}2 \text { weeks } \\
\text { any treatment period }\end{array}$} & \multirow{3}{*}{$\begin{array}{l}2 \text { weeks } \\
\text { any visits }\end{array}$} & \\
\hline Measurement unit & Number of days & any visits & & & & \\
\hline \multicolumn{4}{|l|}{ Indonesia } & & & \\
\hline Reference period & 12 months & 1 month & n.a. & 1 month & 1 month & \multirow[b]{2}{*}{$\begin{array}{l}\text { Puskesmas (inpatients and } \\
\text { outpatients) and } \\
\text { supplementary Puskesmas } \\
\text { (outpatients) included in } \\
\text { health centre/polyclinic. } \\
\text { Polindes and Posyandu in } \\
\text { antenatal care. }\end{array}$} \\
\hline Measurement unit & Number of days & $\begin{array}{l}\text { Number of } \\
\text { visits }\end{array}$ & n.a. & $\begin{array}{l}\text { Number of visits, } \\
\text { Number of days for } \\
\text { inpatient }\end{array}$ & $\begin{array}{l}\text { Number of } \\
\text { visits }\end{array}$ & \\
\hline
\end{tabular}




\begin{tabular}{|c|c|c|c|c|c|c|}
\hline & \multicolumn{2}{|c|}{ Hospital care } & \multirow[b]{2}{*}{ Doctor visits } & \multirow{2}{*}{$\begin{array}{l}\text { Nonhospital care } \\
\text { Polyclinic/health } \\
\text { center }\end{array}$} & \multirow[b]{2}{*}{ Antenatal care } & \multirow[b]{2}{*}{ Comments } \\
\hline & Inpatients & outpatients & & & & \\
\hline \multicolumn{7}{|l|}{ Malaysia } \\
\hline Reference period & 12 months & 2 weeks & \multirow{2}{*}{ n.a. } & 2 weeks & \multirow{2}{*}{ n.a. } & \\
\hline Measurement unit & $\begin{array}{l}\text { Number of } \\
\text { admissions }\end{array}$ & $\begin{array}{l}\text { Number of } \\
\text { visits }\end{array}$ & & Number of visits & & \\
\hline \multicolumn{7}{|l|}{ Nepal } \\
\hline Reference period & & 30 days & n.a. & 30 days & n.a. & \multirow{5}{*}{$\begin{array}{l}\text { Data does not allow distinction } \\
\text { between hospital IP and OP }\end{array}$} \\
\hline Measurement unit & & $\begin{array}{l}\text { Number of } \\
\text { visits }\end{array}$ & n.a. & Number of visits & n.a. & \\
\hline \multirow{3}{*}{\multicolumn{6}{|c|}{$\begin{array}{l}\text { Sri Lanka } \\
\text { Reference period } \\
\text { Measurement unit }\end{array}$}} & \\
\hline & & & & & & \\
\hline & & & & & & \\
\hline \multicolumn{7}{|l|}{ Thailand } \\
\hline Reference period & 12 months & 1 month & \multirow{2}{*}{ n.a. } & 1 month & \multirow{2}{*}{ n.a. } & \multirow[b]{2}{*}{$\begin{array}{l}\text { A distinction is made between } \\
\text { public and private care only } \\
\text { for the last } 2 \text { IP admissions } \\
\text { and the last episode of other } \\
\text { care. Assumed all care } \\
\text { received in same sector }\end{array}$} \\
\hline Measurement unit & $\begin{array}{l}\text { Number of } \\
\text { admissions }\end{array}$ & $\begin{array}{l}\text { Number of } \\
\text { visits }\end{array}$ & & Number of visits & & \\
\hline \multicolumn{7}{|l|}{ Vietnam } \\
\hline Reference period & 12 months & 4 weeks & \multirow[t]{2}{*}{ n.a. } & 4 weeks & \multirow[t]{2}{*}{ n.a. } & \multirow{2}{*}{$\begin{array}{l}\text { No distinction between public } \\
\text { and private sector for IP care. } \\
\text { Since vast majority of } \\
\text { hospitals were public, } \\
\text { assumed all IP is public }\end{array}$} \\
\hline Measurement unit & Number of days & $\begin{array}{l}\text { Number of } \\
\text { visits }\end{array}$ & & Number of visits & & \\
\hline
\end{tabular}

IP inpatient.

OP outpatient.

n.a. not applicable. 
TABLE S3. Summary indices of incidence of incidence of the public healthcare subsidy

\begin{tabular}{|c|c|c|c|c|}
\hline & \multicolumn{2}{|c|}{ Hospital care } & \multirow[b]{2}{*}{ Non-hospital care } & \multirow[b]{2}{*}{ Total public subsidy } \\
\hline & Inpatient & Outpatient & & \\
\hline \multicolumn{5}{|l|}{ Bangladesh } \\
\hline Concentration index & $0.2325(0.1154)$ & $0.1356(0.0360)$ & $0.0474(0.0838)$ & $0.1588(0.0609)$ \\
\hline Kakwani index & $-0.1338(0.0909)$ & $-0.2388(0.0372)$ & $-0.3358(0.0692)$ & $-0.2244(0.0499)$ \\
\hline Subsidy share & $47.99 \%$ & $25.33 \%$ & $26.69 \%$ & $100 \%$ \\
\hline \multicolumn{5}{|l|}{ Gansu (China) } \\
\hline Concentration index & $0.2442(0.0509)$ & $0.1199(0.0373)$ & $0.1199(0.0373)$ & $0.1970(0.0365)$ \\
\hline Kakwani index & $-0.2286(0.0439)$ & $-0.3529(0.0360)$ & $-0.3529(0.0360)$ & $-0.2758(0.0332)$ \\
\hline Subsidy share & $65.42 \%$ & $34.58 \%$ & $34.58 \%$ & $100 \%$ \\
\hline \multicolumn{5}{|l|}{ Heilongjiang (China) } \\
\hline Concentration index & $0.03232(0.0605)$ & $0.2192(0.0474)$ & $0.2192(0.0474)$ & $0.2527(0.0385)$ \\
\hline Kakwani index & $-0.1242(0.0652)$ & $-0.2281(0.0510)$ & $-0.2281(0.0510)$ & $-0.1946(0.0424)$ \\
\hline Subsidy share & $60.09 \%$ & $39.91 \%$ & $39.91 \%$ & $100 \%$ \\
\hline \multicolumn{5}{|l|}{ Hong Kong SAR } \\
\hline Concentration index & $-0.3193(0.0355)$ & $-0.2762(0.0264)$ & $-0.2444(0.0232)$ & $-0.3104(0.300)$ \\
\hline Kakwani index & $-0.6919(0.0356)$ & $-0.6491(0.0265)$ & $-0.6173(0.0232)$ & $-0.6831(0.0301)$ \\
\hline Subsidy share & $82.47 \%$ & $13.36 \%$ & $4.17 \%$ & $100 \%$ \\
\hline \multicolumn{5}{|l|}{ India } \\
\hline Concentration index & $0.2630(0.0193)$ & $0.00296(0.0211)$ & $-0.1325(0.0328)$ & $0.2117(0.0164)$ \\
\hline Kakwani index & $0.0122(0.01928)$ & $-0.2476(0.02113)$ & $-0.3830(0.03281)$ & $-0.0390(0.0165)$ \\
\hline Subsidy share & $83.68 \%$ & $9.62 \%$ & $6.65 \%$ & $100 \%$ \\
\hline \multicolumn{5}{|l|}{ Indonesia } \\
\hline Concentration index & $0.4896(0.0254)$ & $0.3891(0.0186)$ & $-0.0078(0.0045)$ & $0.1822(0.0081)$ \\
\hline Kakwani index & $0.1752(0.0248)$ & $0.0880(0.0187)$ & $-0.3142(0.0047$ & $-0.1245(0.0080)$ \\
\hline Subsidy share & $26.54 \%$ & $14.86 \%$ & $58.59 \%$ & $100 \%$ \\
\hline \multicolumn{5}{|l|}{ Malaysia } \\
\hline Concentration index & $-0.0416(0.0124)$ & $-0.0165(0.0231)$ & $-0.2410(0.0181)$ & $-0.0807(0.0116)$ \\
\hline Kakwani index & $-0.4100(0.0131)$ & $-0.3863(0.0235)$ & $-0.3863(0.0235)$ & $-0.4493(0.0123)$ \\
\hline
\end{tabular}


TABLE S3. Continued

\begin{tabular}{|c|c|c|c|c|}
\hline & \multicolumn{2}{|c|}{ Hospital care } & \multirow[b]{2}{*}{ Non-hospital care } & \multirow[b]{2}{*}{ Total public subsidy } \\
\hline & Inpatient & Outpatient & & \\
\hline \multicolumn{5}{|l|}{ Nepal } \\
\hline Concentration index & $0.3422(0.0709)$ & $0.3422(0.0709)$ & $0.1865(0.0411)$ & $0.2541(0.0398)$ \\
\hline Kakwani index & $0.1268(0.0605)$ & $0.1268(0.0605)$ & $-0.0677(0.0487)$ & $0.0384(0.405)$ \\
\hline Subsidy share & $54.58 \%$ & $54.58 \%$ & $45.24 \%$ & $100 \%$ \\
\hline \multicolumn{5}{|l|}{ Sri Lanka } \\
\hline Concentration index & $0.0220(0.0377)$ & $-0.0486(0.0304)$ & $-0.0486(0.0304)$ & $-0.0020(0.0269)$ \\
\hline Kakwani index & $-0.3313(0.0252)$ & $-0.4042(0.0172)$ & $-0.4042(0.0172)$ & $-0.3561(0.0284)$ \\
\hline Subsidy share & $68.00 \%$ & $32.00 \%$ & $32.00 \%$ & $100 \%$ \\
\hline \multicolumn{5}{|l|}{ Thailand } \\
\hline Concentration index & $-0.0242(0.0308)$ & $-0.0392(0.0227)$ & $-0.2506(0.0325)$ & $-0.0404(0.0195)$ \\
\hline Kakwani index & $-0.4199(0.0317)$ & $-0.4348(0.0242)$ & $-0.6463(0.0335)$ & $-0.4361(0.0210)$ \\
\hline Subsidy share & $50.74 \%$ & $45.16 \%$ & $4.18 \%$ & $100 \%$ \\
\hline Kakwani index & $-0.1495(0.0471)$ & $-0.0599(0.0667)$ & -0.4623 & $-0.2573(0.0458)$ \\
\hline Subsidy share & $86.88 \%$ & $2.13 \%$ & $10.98 \%$ & $100 \%$ \\
\hline
\end{tabular}

Robust standard errors in parentheses.

Source: Authors' calculations from data documented in table S-1. 
Table S4. Cross-country Dominance of Public Health Subsidy Concentration Curves

\begin{tabular}{|c|c|c|c|c|c|c|c|c|c|c|}
\hline Total subsidy & Malaysia & Thailand & Sri Lanka & Vietnam & Bangladesh & Indonesia & Gansu & India & Heilongjiang & Nepal \\
\hline Hong Kong SAR & $D^{*}$ & $D^{*}$ & $D^{*}$ & $\mathrm{D}$ & $D^{*}$ & $D^{*}$ & $D^{*}$ & $D^{*}$ & $D^{*}$ & $D^{*}$ \\
\hline Malaysia & & n.s. & n.s. & $\mathrm{D}$ & $\mathrm{D}$ & $D^{*}$ & $D^{*}$ & $D^{*}$ & $D^{*}$ & $D^{*}$ \\
\hline Thailand & & & n.s. & $\mathrm{D}$ & $\mathrm{D}$ & $D^{*}$ & $\mathrm{D}$ & $D^{*}$ & $D^{*}$ & $D^{*}$ \\
\hline Sri Lanka & & & & n.s. & n.s. & $\mathrm{D}$ & $\mathrm{D}$ & $D^{*}$ & $D^{*}$ & $D^{*}$ \\
\hline Vietnam & & & & & $\mathrm{D}$ & $D^{*}$ & $D^{*}$ & $\mathrm{D}$ & $\mathrm{D}$ & $D^{*}$ \\
\hline Bangladesh & & & & & & n.s. & n.s. & n.s. & n.s. & n.s. \\
\hline Indonesia & & & & & & & $\mathrm{D}$ & n.s. & n.s. & $\mathrm{D}$ \\
\hline Gansu (China) & & & & & & & & & n.s. & n.s. \\
\hline India & & & & & & & $\mathrm{D}$ & & n.s. & $\mathrm{D}$ \\
\hline Heilongjiang (China) & & & & & & & & & & n.s. \\
\hline Hospital inpatient subsidy & Malaysia & Thailand & Sri Lanka & Vietnam & Bangladesh & Gansu & India & Heilongjiang & Nepal & Indonesia \\
\hline Hong Kong SAR & $D^{*}$ & $D^{*}$ & $D^{*}$ & $\mathrm{D}$ & $\mathrm{D}$ & $D^{*}$ & $D^{*}$ & $D^{*}$ & $D^{*}$ & $D^{*}$ \\
\hline Malaysia & & n.s. & n.s. & $\mathrm{D}$ & n.s. & $D^{*}$ & $D^{*}$ & $D^{*}$ & $D^{*}$ & $\mathrm{D}^{*}$ \\
\hline Thailand & & & n.s. & $\mathrm{D}$ & n.s. & $\mathrm{D}$ & $D^{*}$ & $\mathrm{D}$ & $D^{*}$ & $D^{*}$ \\
\hline Sri Lanka & & & & n.s. & n.s. & $\mathrm{D}$ & $D^{*}$ & $\mathrm{D}$ & $D^{*}$ & $D^{*}$ \\
\hline Vietnam & & & & n.s. & & $\mathrm{D}$ & $\mathrm{D}$ & $\mathrm{D}$ & $D^{*}$ & $\mathrm{D}$ \\
\hline Bangladesh & & & & & & n.s. & n.s. & n.s. & n.s. & n.s. \\
\hline Gansu (China) & & & & & & & n.s. & n.s. & n.s. & n.s. \\
\hline India & & & & & & & & n.s. & $\mathrm{D}$ & $D^{*}$ \\
\hline Heilongjiang (China) & & & & & & & & & n.s. & n.s. \\
\hline Nepal $^{\mathrm{a}}$ & & & & & & & & & & \\
\hline Indonesia & & & & & & & & & $\mathrm{D}$ & \\
\hline Hospital outpatient subsidy & Sri Lanka & Thailand & Malaysia & India & Gansu & Bangladesh & Vietnam & Heilongjiang & Indonesia & \\
\hline Hong Kong SAR & $D^{*}$ & $D^{*}$ & $\mathrm{D}$ & $D^{*}$ & $D^{*}$ & $\mathrm{D}$ & $D^{*}$ & $D^{*}$ & $D^{*}$ & \\
\hline Sri Lanka & & n.s. & n.s. & n.s. & $\mathrm{D}$ & $\mathrm{D}$ & $D^{*}$ & $\mathrm{D}$ & $D^{*}$ & \\
\hline Thailand & & & n.s. & n.s. & D & $\mathrm{D}$ & $\mathrm{D}$ & $\mathrm{D}$ & $D^{*}$ & \\
\hline
\end{tabular}


TABle S4. Continued

\begin{tabular}{|c|c|c|c|c|c|c|c|c|c|c|}
\hline Total subsidy & Malaysia & Thailand & Sri Lanka & Vietnam & Bangladesh & Indonesia & Gansu & India & Heilongjiang & Nepal \\
\hline Malaysia & & & & n.s. & $\mathrm{D}$ & $\mathrm{D}$ & $D^{*}$ & $\mathrm{D}$ & $D^{*}$ & \\
\hline India & & & & & $\mathrm{D}$ & $\mathrm{D}$ & $D^{*}$ & $\mathrm{D}$ & $D^{*}$ & \\
\hline Gansu (China) & & & & & & n.s. & n.s. & n.s. & $\mathrm{D}$ & \\
\hline Bangladesh & & & & & & & n.s. & n.s. & $\mathrm{D}$ & \\
\hline Vietnam & & & & & & & & n.s. & $\mathrm{D}$ & \\
\hline Heilongjiang (China) & & & & & & & & & $\mathrm{D}$ & \\
\hline Non-hospital subsidy & Hong Kong & Malaysia & India & Vietnam & Indonesia & Bangladesh & Nepal & & & \\
\hline Thailand & $\mathrm{D}$ & $\mathrm{D}$ & $\mathrm{D}$ & $\mathrm{D}$ & $D^{*}$ & $\mathrm{D}$ & $D^{*}$ & & & \\
\hline Hong Kong SAR & & n.s. & $\mathrm{D}$ & $\mathrm{D}$ & $D^{*}$ & $D *$ & $D *$ & & & \\
\hline Malaysia & & & $\mathrm{D}$ & $\mathrm{D}$ & $\mathrm{D}$ & $\mathrm{D}$ & $D^{*}$ & & & \\
\hline India & & & & n.s. & $D^{*}$ & $\mathrm{D}$ & $D^{*}$ & & & \\
\hline Vietnam & & & & & $\mathrm{D}$ & $\mathrm{D}$ & $D^{*}$ & & & \\
\hline Indonesia & & & & & & n.s. & $D^{*}$ & & & \\
\hline Bangladesh & & & & & & & n.s. & & & \\
\hline
\end{tabular}

Note: Countries/provinces are ranked from most to least propoor according to values of concentration indices.

Tests follow the multiple comparison approach with the null hypothesis defined as curves being indistinguishable. n.s. indicates failure to reject the null at 5\% significance.

$\mathrm{D}$ indicates that the subsidy concentration curve of the row country/province dominates (is more pro-poor) than that of the column country/province. There are no cases of crossing concentration curves.

*indicates that the intersection union principle test rejects the (different) null of nondominance against the alternative of strict dominance at $5 \%$. If no "appears, then this test does not reject its null.

acomparison with Nepal are for the aggregate of inpatient and outpatient subsidies. 
TABLE S 5. National Income and Government Expenditure on Health

\begin{tabular}{|c|c|c|c|c|c|}
\hline Territory & Year $^{\mathrm{a}}$ & $\begin{array}{c}\text { GDP per capita, } \\
\text { PPP } \$^{\mathrm{b}}\end{array}$ & $\begin{array}{l}\text { General government } \\
\text { expenditure on } \\
\text { health as } \% \mathrm{GDP}^{\mathrm{c}}\end{array}$ & $\begin{array}{l}\text { General government } \\
\text { expenditure on health } \\
\text { per capital, PPP \$ }\end{array}$ & $\begin{array}{c}\text { General government expenditure } \\
\text { on health as } \% \text { total } \\
\text { expenditure on health }\end{array}$ \\
\hline Bangladesh & 1999 & 1495 & 0.98 & 15 & 27 \\
\hline China & 2002 & 4568 & 2.26 & 103 & 42 \\
\hline Gansu (China) & 2002 & 2661 & 2.38 & 63 & 42 \\
\hline $\begin{array}{l}\text { Heilongjiang } \\
\text { (China) }\end{array}$ & 2002 & 5434 & 1.48 & 80 & 36 \\
\hline $\begin{array}{l}\text { Hong Kong } \\
\text { SAR }\end{array}$ & $2001 / 02$ & 26049 & 3.26 & 849 & 57 \\
\hline India & 1996 & 1994 & 0.81 & 16 & 16 \\
\hline Indonesia & 2001 & 3146 & 0.57 & 18 & 36 \\
\hline Malaysia & 1996 & 8254 & 1.34 & 111 & 58 \\
\hline Nepal & $1995 / 96$ & 1179 & 1.20 & 14 & 24 \\
\hline Sri Lanka & $1996 / 97$ & 2951 & 1.63 & 48 & 50 \\
\hline Thailand & 2000 & 6740 & 2.04 & 138 & 61 \\
\hline Vietnam & 1998 & 1854 & 1.44 & 27 & 33 \\
\hline
\end{tabular}

${ }^{\text {a}}$ Year of survey used for distributional analysis.

${ }^{b}$ GDP per capita in international \$ using purchasing power parity (PPP) exchange rates. Constant year 2000 prices.

${ }^{\mathrm{c}} \mathrm{General}$ government expenditure on health including social insurance.

Source: GDP per capita-World Development Indicators, World Bank. Health expenditures-National health accounts estimates, except: India, Malaysia and Vietnam from World Health Report, Stastistical Annexes, WHO, and Nepal from (HMG/Nepal 2000 and Hotchkiss, Rous and others 1998). 
TABLE S6. Charges and exemptions for public healthcare

\begin{tabular}{|c|c|c|c|c|}
\hline & Charged services & Free Services & Income/poverty related fee waivers & $\begin{array}{c}\text { Nonpoor groups exempt from } \\
\text { charges }\end{array}$ \\
\hline Bangladesh & $\begin{array}{l}\text { Secondary services (nominal } \\
\text { registration fee for inpatient/ } \\
\text { outpatient); Inpatient care in } \\
\text { major hospitals }\end{array}$ & $\begin{array}{l}\text { Most primary care (or local } \\
\text { services); medicines within } \\
\text { facility; immunization; some } \\
\text { reproductive healthcare }\end{array}$ & Poor exempt or pay lower charge & Civil servants (selected services) \\
\hline China & $\begin{array}{l}\text { Inpatient (including etc } \\
\text { medicines); Outpatient } \\
\text { (including medicines); } \\
\text { Immunisation }\end{array}$ & Family planning & None & $\begin{array}{l}\text { Old Red Army soldiers and } \\
\text { Retirees }\end{array}$ \\
\hline $\begin{array}{l}\text { Hong Kong } \\
\text { SAR }\end{array}$ & $\begin{array}{l}\text { Inpatient (including medicines); } \\
\text { outpatient (including } \\
\text { medicines); dental }\end{array}$ & $\begin{array}{l}\text { Accident and emergency (until } \\
\text { December 2002) }\end{array}$ & Welfare recipients exempt & $\begin{array}{l}\text { Civil servants and dependents } \\
\text { (reduced rate for Inpatients); } \\
\text { hospital staff and dependents }\end{array}$ \\
\hline India & $\begin{array}{l}\text { Inpatient bed charge; } \\
\text { outpatient registration } \\
\text { charge; certain medicines; } \\
\text { tests/x-rays; dental }\end{array}$ & $\begin{array}{l}\text { Hospital consultation and certain } \\
\text { medicines. Primary care/health } \\
\text { center/polyclinic consultation } \\
\text { and medicines. Family planning. } \\
\text { Vaccinations and immunizations }\end{array}$ & $\begin{array}{l}\text { None formally. Indirect relation to } \\
\text { income through price } \\
\text { differentiation in inpatient care. } \\
\text { Informally, "poor" can be } \\
\text { exempted partially or fully from } \\
\text { charges }\end{array}$ & Civil sevants \\
\hline Indonesia & All medical care and medicines & None & $\begin{array}{l}\text { Poor exempt from all charges. } \\
\text { Indirect relation of inpatient } \\
\text { charges to income through price } \\
\text { discrimination }\end{array}$ & $\begin{array}{l}\text { Charges determined at local } \\
\text { government level. Some better } \\
\text { off local govts. Provide free } \\
\text { health centre care }\end{array}$ \\
\hline Malaysia & $\begin{array}{l}\text { Hospital inpatient and } \\
\text { outpatient. Primary care. } \\
\text { Dental care. Diagnostics and } \\
\text { x-rays }\end{array}$ & $\begin{array}{l}\text { Family planning and vaccinations/ } \\
\text { immunizations. Outpatient ante } \\
\text { and postnatal care. Treatment of } \\
\text { infectious diseases on third class } \\
\text { wards. Dental care for pregnant } \\
\text { women and pre school children }\end{array}$ & $\begin{array}{l}\text { Hospital directors have discretion } \\
\text { to waive fees for destitute. } \\
\text { Upper limit on charges for third } \\
\text { class ward patients }\end{array}$ & $\begin{array}{l}\text { Infants less than } 1 \text { year } \\
\text { (outpatient). State rulers, } \\
\text { Governors and families. Civil } \\
\text { servants (including retired) } \\
\text { and dependents. Local } \\
\text { authority employees and } \\
\text { dependents }\end{array}$ \\
\hline
\end{tabular}




\section{Nepal}

All medical care and medicines. Nominal charge for outpatient varying with facility.

Sri Lanka Family planning services. Patients occasionally asked to buy medicines/supplies from private retailers when out of stock at facility.

Thailand All medical care and medicines. Nonpersonal healthcare; EPI After Oct 2001, fixed fee (30 Baht) UC scheme means very minimal co-payment.

Vietnam Fees for most services introduced in 1989. Medicines rarely provided free of charge.
Poor either exempt or pay reduced None charge but not fully

implemented. vaccines, immunization and reproductive health services. $60 \%$ subsidy for medicines at Health Posts and Primary Care centres.

All medical and medicines except family planning.

\section{vaccination}

Outpatient services at commune health centres.
No official exemptions, but limited None survey evidence suggests that facility staff tend to avoid asking the poorest patients to selfpurchase medicines and supplies, or ration available stocks to

them.

Poor exempted from user fees and co-payments. Informally, those "unable to pay" are exempted.

children $<12$; elderly $>60$; public health volunteers; monks.

Fee exemptions for individuals who have certification of

Families of health personnel, certain classes of patients (like handicapped, TB), orphans. 


\section{REFERENCES}

Beach, Charles M., and James Richmond. 1985. "Joint Confidence Intervals for Income Shares and Lorenz Curves.” International Economic Review 26:439-50.

Besley, Timothy, and Stephen Coate. 1991. "Public Provision of Private Goods and the Redistribution of Income.” American Economic Review 81(4):979-84.

Bishop, John A., K. Victor Chow, and John P. Formby. 1994. "Testing for Marginal Changes in Income Distributions with Lorenz and Concentration Curves.” International Economic Review 35(2):479-88.

Bishop, John A., John P. Formby, and Paul D. Thistle. 1992. "Convergence of the South and Non-South Income Distributions, 1969-1979." American Economic Review 82(1):262-72.

Caldwell, John C. 1986. "Routes to Low Mortality in Poor Countries." Population and Development Review 12(2):171-220.

Castro-Leal, Florencia, Julia Dayton, Lionel Demery, and Kalpana Mehra. 2000. "Public Spending on Health Care in Africa: Do the Poor Benefit?" Bulletin of the World Health Organisation $78(1): 66-74$.

Dardanoni, Valentino, and Antonio Forcina. 1999. "Inference for Lorenz Curve Orderings." Econometrics Journal 2(1):49-75.

Das, Jishnu, and Jeffrey Hammer. 2005. "Which Doctor? Combining Vignettes and Item Response to Measure Clinical Competence." Journal of Development Economics 78(2):348-83.

Davidson, Russell, and Jean-Yves Duclos. 1997. "Statistical Inference for the Measurement of the Incidence of Taxes and Transfers." Econometrica 65(6):1453-65.

Deaton, Angus. 1997. The Analysis of Household Surveys: A Microeconometric Approach to Development Policy. Baltimore, MD: Johns Hopkins University Press.

Filmer, Deon. 2003. "The Incidence of Public Expenditures on Health and Education." Background note for the World Development Report 2004: Making Services Work for the Poor. Washington, D.C.: World Bank.

Gwatkin, Davidson R., Shea Rustein, Kiersten Johnson, Roshni Pande, and Adam Wagstaff. 2003. Initial Country-Level Information about Socio-Economic Differentials in Health, Nutrition and Population, vols.I and II. Washington, D.C.: World Bank, Health, Population, and Nutrition Division.

Hammer, Jeffrey S., Ijaz Nabi, and James A. Cercone. 1995. "Distributional Effects of Social Sector Expenditures in Malaysia, 1974-89." In Walle Domenique van de, and Nead Kimberly eds., Public Spending and the Poor. Baltimore, MD: Johns Hopkins University Press.

Howes, Stephen. 1996. “A New Test for Inferring Dominance from Sample Data." World Bank, Washington, D.C.

Hsiao, William. 2000. "A Preliminary Assessment of Sri Lanka's Health Sector and Steps Forward.” Cambridge, Mass.: Harvard School of Public Health.

Kaur, Aamrjot, B. L. S. Prakasa Rao, and Harshinder Singh. 1994. "Testing for Second-Order Stochastic Dominance of Two Distributions.” Econometric Theory 10(5):849-66.

Lanjouw, Peter, and Martin Ravallion. 1999. "Benefit Incidence, Public Spending Reforms and the Timing of Program Capture." World Bank Economic Review 13(2):257-73.

Leung, Gabriel M., Keith Tin, and Owen O’Donnell. 2005. "Redistribution or Horizontal Equity in Hong Kong's Mixed Public-Private Health System: A Policy Conundrum.” EQUITAP Working Paper 22, Erasmus, Rotterdam, Netherlands, and Institute for Policy Studies, Colombo.

Mahal, Ajay, Janmejaya Sing, Farzana Afridi, Vikram Lamba, Anil Gumber, and V Selvaraju. 2000. "Who Benefits from Public Health Spending in India?" New Delhi: National Council for Applied Economic Research.

McNay, Kirsty, Regina Keith, and Angela Penrose. 2004. Bucking the Trend: How Sri Lanka Has Achieved Good Health at Low Cost-Challenges and Policy Lessons for the 21st Century. London: Save the Children. 
Meerman, Jacob. 1979. Public Expenditure in Malaysia: Who Benefits and Why? New York: Oxford University Press.

Rannan-Eliya, Ravindra P. 2001. "Strategies for Improving the Health of the Poor-the Sri Lankan Experience.” Health Policy Programme, Institute of Policy Studies, Colombo.

Sahn, David E., and Stephen D. Younger. 2000. "Expenditure Incidence in Africa: Microeconomic Evidence." Fiscal Studies 21(3):321-48.

Sahn, David E., Stephen D. Younger, and Kenneth R. Simler. 2000. "Dominance Testing of Transfers in Romania." Review of Income and Wealth 46(3):309-27.

Shepard, Donald S., William Savedoff, and Kai Hong Phua. 2002. Health Care Reform Initiatives in Malaysia: Report of a Consultation with the Planning and Development Division, Ministry of Health, Malaysia. Waltham, Mass.: Brandeis University, Shneider Insitute for Health Policy.

Towse, Adrian, Anne Mills, and Viroj Tangcharoensathien. 2004. "Learning from Thailand's Health Reforms.” British Medical Journal 328:103-05.

van de Walle, Domenique. 1995. "The Distribution of Subsidies through Public Health Services in Indonesia, 1978-87." In Dominique van de Walle, and Nead Kimberly eds., Public Spending and the Poor. Baltimore, MD: Johns Hopkins University Press.

van de Walle, Domenique. 1998. "Assessing the Welfare Impacts of Public Spending." World Development 26(3):365-79.

Van Doorslaer, Eddy, and Cristina Masseria, Xander Koolman and the OECD Health Group Equity Research. 2006. "Inequalities in Access to Medical Care by Income in Developed Countries." Canadian Medical Association Journal 174(2):177-83.

Victora, C. G., J. P. Vaughan, F. C. Barros, A. C. Silva, and E Tomasi. 2000. "Explaining Trends in Inequalities: Evidence from Brazilian Child Health Studies.” The Lancet 356(9235):1093-98.

World Bank. 2001. Vietnam: Growing Healthy-A Review of Vietnam's Health Sector. Hanoi.

World Bank. Various years. World Development Indicators. Washington, D.C.

World Health Organization. Various years. World Health Report: Statistical Annexes. Geneva. 
Reproduced with permission of the copyright owner. Further reproduction prohibited without permission. 